УДК 37.014.3(477)-051]:334.7:005.336.2

DOI https://doi.org/10.32782/apv/2021.6.6

\title{
Тетяна БОРТНЮК
}

кандидат економічних наук, дочент, Комунальний заклад вищої освіти «Луиький педагогічний коледж» Волинської обласної ради, просп. Волі, 36, м. Луцьк, Украӥна, 43010

ORCID: 0000-0001-9673-1366

Бібліографічний опис статті: Бортнюк, Т. (2021). Підприємницька компетентність майбутнього вчителя початкової школи: компонентна структура. Acta Paedagogica Volynienses, 6, 33-39, doi: https://doi.org/10.32782/apv/2021.6.6

\section{ПІДПРИСМНИЦЬКА КОМПЕТЕНТНІСТЬ МАЙБУТНЬОГО ВЧИТЕЛЯ ПОЧАТКОВОЇ ШКОЛИ: КОМПОНЕНТНА СТРУКТУРА}

У статті виокремлено й проаналізовано окремі аспекти структурно-компонентної характеристики феномену «підприємницька компетентність майбутнього вчителя початкової школи». У ракурсі проблемного поля дослідження репрезентовано наукові пошуки формування підприємницької компетентності як інноваційного елемента компетентнісної парадигми у різних освітніх площинах $і$ констатовано потребу чіткого розуміння структури поняття «підприємницька компетентність майбутнього вчителя початкової школи». Зважаючи на різновекторність досліджень сутності підприємницької компетентності для визначення структурних компонентів поняття «підприємницька компетентність майбутнього вчителя початкової школи», послугувалися наявними фундаментальними науковими студіями, передусім, економічного спрямування. 3 урахуванням наукових позииій визначено і охарактеризовано взаємопов'язані структурні компоненти підприємницької компетентності майбутнього вчителя початкової школи: аксіологічно-мотиваційний, інформаційно-когнітивний, функційнодіяльнісний, особистісно-рефлексивний. Аксіологічно-мотиваційний компонент зумовлює розуміння студентами системи иіннісних властивостей сучасного розвитку підприємливості у професійно-педагогічній діяльності, изіннісних смислів підприємнищької діяльності, морально-етичного ставлення до обраної професії. Інформаційнокогнітивний компонент акумулює сукупність знань підприємницького спрямування та методично зорієнтованих. Функиійно-діяльнісний компонент відображає здатність майбутнього вчителя початкової школи планувати, організовувати, проєктувати, контролювати продуктивну підприємницьку професійно-педагогічну діяльність, генерувати нові ідеї й ініціативи та втілювати їх у життя, комунікувати, швидко приймати альтернативні рішення, а також методичних умінь формувати підприємницьку компетентність в учнів початкової школи. Особистісно-рефлексивний компонент представлений особистісно адаптивною та рефлексивною компетентністю.

Ключові слова: компетентнісна парадигма, майбутній учитель, підприємницька компетентність, початкова школа, структура, структурно-компонентна характеристика, иүілісна система.

\section{Tatiana BORTNYUK}

Candidate of Economic Sciences, Associate Professor, Lutsk Pedagogical College, Volyn Regional Council, 36 Volia Ave., Lutsk, Ukraine, 43010

ORCID: 0000-0001-9673-1366

To cite this article: Bortniuk, T. (2021). Pidpryiemnytska kompetentnistmaibutnoho vchytelia pochatkovoi shkoly: komponentna struktura [Entrepreneurial competence of the future primary school teacher: component structure]. Acta Paedagogica Volynienses, 6, 33-39, doi: https://doi.org/10.32782/apv/2021.6.6

\section{ENTREPRENEURIAL COMPETENCE OF THE FUTURE PRIMARY SCHOOL TEACHER: COMPONENT STRUCTURE}

The article highlights and analyzes some aspects of the structural and component characteristics of the phenomenon "entrepreneurial competence of the future primary school teacher". In the plane of the problem field of research the scientific research of formation of entrepreneurial competence as an innovative element of competence competence paradigm in different educational planes is represented and the need of clear understanding of structure of concept "entrepreneurial competence of the future primary school teacher" is stated. Given the diversity of research on the essence of entrepreneurial competence to determine the structural components of the concept of "entrepreneurial competence of future primary school teachers" used the existing basic research studies, especially economic direction. Taking into account scientific 
positions, the interconnected structural components of entrepreneurial competence of the future primary school teacher are identified and characterized: axiological-motivational, information-cognitive, functional-activity, personal-reflexive. The axiological-motivational component determines the students'understanding of the system of value properties of modern entrepreneurship development in professional and pedagogical activity, value meanings of entrepreneurial activity, moral and ethical attitude to the chosen profession. The information-cognitive component involves students' understanding of the role of entrepreneurship, its economic and legal foundations in modern society, in the knowledge economy, market relations; characterizes the ability of the future primary school teacher to quickly obtain the necessary information and operate it for personal self-realization, innovation or change in the implementation of the competence paradigm of learning. Functional component reflects the ability of future primary school teachers to plan, organize, design, control productive entrepreneurial professional and pedagogical activities, generate new ideas and initiatives and implement them, communicate, quickly make alternative decisions, showing the formation of professionally relevant skills, innovation, creativity, as well as methodological skills to form entrepreneurial competence in primary school students. The personality-reflexive component is represented by personality-adaptive and reflexive competence.

Key words: competence paradigm, future teacher, entrepreneurial competence, primary school, structure, structuralcomponent characteristics, integral system.

Постановка наукової проблеми таїїначення. Актуальність проблеми формування підприємницької компетентності майбутнього вчителя початкової школи зумовлена стратегічними завданнями, що мають глибинний характер, орієнтуючи професійну освіту на підготовку майбутніх фахівців, ініціативних, самостійних, підприємливих та креативних, умотивованих до отримання якісних знань, формування професійних компетентностей, необхідних для забезпечення високого рівня життя і зайнятості, сприяння соціальній згуртованості для сталого розвитку суспільства, що прагнуть вибудовувати стратегічну лінію власного професійного вдосконалення. Підприємницька компетентність, на думку науковців (Ю. Білова, Н. Морзе, Н. Балик, О. Проценко, С. Прищепа, М. Стрельніков та ін.), є інтегративним утворенням, що виявляється у мотивованій здатності до творчого пошуку, реалізації нових ідей та дає змогу вирішувати різноманітні проблеми у повсякденному, професійному, соціальному житті (Морзе, Балик, 2015), як складний, суперечливий, різнорівневий процес, який передбачає опанування особистістю підприємницьких знань, становлення підприємницької поведінки за умови відповідного формування свідомості (Проценко, 2013). Відтак це спонукає аналізувати феномен «підприємницька компетентність майбутнього вчителя початкової школи» як цілісну систему, інваріантом якої варто розглядати іiї структуру, котра віддзеркалює сукупність певних компонентів, що містить система, способи їх взаємодії, визначається характером логічних зв'язків між окремими ії елементами.

Аналіз останніх досліджень i публікацій засвідчує розвідки, де репрезентовано наукові пошуки формування підприємницької компетент- ності як інноваційного елемента компетентнісної парадигми у різних освітніх площинах, а саме: розроблення моделі формування підприємницької компетентності у майбутніх учителів технологій (Земка, 2017); фахової компетентності з основ підприємництва у майбутніх учителів технологій (Ляшенко, 2016); розкриття особливостей та опис розвитку підприємливості учнів старшої школи в процесі технологічної освіти (Пискун, Сокол, 2018); дослідження підприємницької компетентності майбутніх менеджерів сфери туризму (Бондар, 2016).

Низка робіт висвітлює сутність і структуру підприємницької компетентності майбутніх фахівців певного професійного спрямування: економічного профілю (Білова, 2013); ресторанного господарства (Ткаченко, 2018); сфери обслуговування (Майковська, 2017). Водночас потребує чіткого розуміння структура поняття «підприємницька компетентність майбутнього вчителя початкової школи».

Мета статті - виокремлення й аналіз окремих аспектів структурно-компонентної характеристики феномену «підприємницька компетентність майбутнього вчителя початкової школи».

Виклад основного матеріалу. Передусім, ми виходимо 3 того, що підставою для визначення структури феномену «підприємницька компетентність майбутнього вчителя початкової школи» $є$ розуміння структури, за визначенням Д. Пріми, як системи відношень відповідних елементів, які утворюють нове ціле (Пріма, 2019); як сукупності взаєморозміщених і взаємопов'язаних складових частин цілого за наявності між ними внутрішніх стійких зв'язків, що забезпечують збереження основних властивостей об'єкта за різних зовнішніх і внутрішніх 
впливів, спираючись на ідеї щодо поліфункційності компетентності (Майковська, 2017).

При цьому 3 позиції системного підходу структура (у складі цілого), як слушно наголошує О. Листопад (Листопад, 2015), виконує подвійну роль: з одного боку, вона сприяе формуванню нових властивостей цілого, перебуваючи у взаємозв'язку 3 іншими зовнішніми і внутрішніми структурами, а з іншого - забезпечує функціонування наявних властивостей.

Зважаючи на різновекторність досліджень сутності підприємницької компетентності (економічні, психологічні, соціологічні, освітні тощо), зумовлених різнобічним характером означеного явища, де первинним $є$ економічний вектор, для визначення структурних компонентів поняття «підприємницька компетентність майбутнього вчителя початкової школи» ми послугувалися наявними фундаментальними науковими студіями, передусім, економічного спрямування. Так, згідно $з$ дослідженнями Ю. Білової, структура підприємницької компетентності майбутніх фахівців економічного профілю охоплює такі компоненти: мотиваційно-ціннісний (внутрішні мотиви, що спонукають особистість до підприємницької діяльності; морально-етичне ставлення до підприємництва і свободи вибору, самореалізації, ощадливості, толерантності як цінностей); когнітивний (сукупність знань про економічну сферу життя суспільства; розуміння сутності методів підприємницької діяльності); діяльнісний (сформованість підприємницької компетентності); емоційно-вольовий (цілеспрямованість; спроможність відкрито ділитися своїми почуттями і переживаннями; витримка, володіння собою в ситуаціях невизначеності; здатність гідно переживати відсутність результату) (Білова, 2013).

Конструктивною нам видається позиція Г. Майковської (2017) щодо презентування структури підприємницької компетентності майбутніх фахівців сфери обслуговування єдністю чотирьох компонентів - інтелектуального (характеризується здатністю до аналізу, синтезу, розроблення й управління проєктами, розуміння сфери та способів використання економічних i базових професійних знань у сфері обслуговування, наявністю навичок вирішення стандартних професійних завдань), організаційно-комунікативного (характери- зується сформованістю мовної та цифрової компетентностей, здатністю до спілкування в професійному й бізнес-середовищі); мотиваційно-иіннісного (характеризується наявністю ціннісних смислів підприємницької діяльності, морально-етичним ставленням до обраної професії, підприємливістю, інноваційністю, ощадливістю); рефлексивно-вольового (характеризується здатністю до самоаналізу, оцінювання й інтерпретації результатів власної професійної діяльності у сфері підприємництва, розв'язання проблем, спроможністю прийняття рішень) (Майковська, 2017).

О. Земка (Земка, 2018) на підставі аналітичного огляду теоретико-методологічних досліджень уточнює структуру підприємницької компетентності учителів технологій, виокремлюючи такі компоненти: мотиваційно-цуіннісний, який синтезує позитивне морально-етичне ставлення до здійснення підприємництва як рушія ринкової економіки, що передбачає повагу до цінностей підприємця нового часу (свободи вибору діяльності, працьовитості, чесності у стосунках зі споживачами, бізнеспартнерами, державою, соціальної відповідальності, ощадливості у використанні обмежених ресурсів тощо), усвідомлення майбутніми педагогами необхідності формування підприємницької компетентності в учнів та визнання домінуючої ролі вчителів технологій у реалізації цього процесу; когнітивний, який об'єднує комплекс знань підприємницького спрямування, що формують економічну та юридичну грамотність майбутніх педагогів, і методичного спрямування, необхідних для ефективної підготовки учнів до здійснення практики підприємництва в рамках освітнього процесу на уроках трудового навчання та технологій; діяльнісний, що характеризується сформованими здатностями планувати, організовувати, контролювати продуктивну підприємницьку діяльність, генерувати бізнес-ідеї, здійснювати маркетингове міні-дослідження ринкового середовища, комунікувати, швидко приймати альтернативні рішення, а також методичними вміннями формувати підприємницьку компетентність в учнів; особистісно-рефлексивний, репрезентований такими особистісними якостями, як цілеспрямованість, самостійність, ініціативність, креативність, мобільність, готовність до виправданого ризику, відповідальність 
за прийняті рішення, розсудливість при розподілі доходів, ощадливість у використанні ресурсів, емоційний інтелект, емпатія, творче та водночас раціональне ставлення до виконання поставлених завдань, здатностями до самоаналізу, об' єктивної самооцінки; уміннями самокорекції (Земка, 2018: 4).

У площині порушеної проблеми вагому значущість має науковий доробок К. Кошевської, учасниці українсько-польського проєкту «Уроки 3 підприємницьким тлом». На переконання польського педагога-психолога, підприємницька компетентність інтегрує вміння спільного встановлення й уточнення принципів роботи на змістовому, організаційному рівнях та рівні взаємовідносин; здатність до порозуміння; емоційний інтелект; здатність формувати толерантну поведінку і сприйняття у мультикультурному середовищі, використовувати творчий потенціал кожного учня; здатність до створення атмосфери співпраці; здатність до самовдосконалення, рефлексії щодо власного розвитку (Кошевська, 2014: 28).

Ми солідарні $з$ думкою І. Гуменюк, що формування підприємницької компетентності майбутніх фахівців початкової освіти $є$ необхідною складовою частиною їхньої професійної підготовки, позаяк «у початковій школі розвиток в учнів підприємницьких якостей пов'язаний не тільки з отриманням економічних знань, але й може відбуватися у змісті інтегрованих уроків iз різних дисциплін, а отже, вбудований в усю систему навчання й виховання. Відповідно, професіограма вчителя початкових класів повинна вміщувати аналогічні якісні характеристики його вмінь та педагогічних настанов, орієнтованих на формування в учнів основ підприємницької компетентності» (Гуменюк, 2019: 54). За твердженням дослідниці, в сучасних освітніх реаліях ( в контексті змістового наповнення дисципліни «Українська мова за професійним спрямуванням») видається можливим чітко виокремити такі види підприємливості майбутнього вчителя початкової школи: часова, інформаційна, прагматична, що є суттєвим у площині порушеної проблеми.

Часова підприємливість - це здатність і практичні вміння особистості ефективно організовувати свій навчальний, робочий, вільний час 3 метою досягнення конкретного результату. Окреслений термін може використовуватися також у значенні кінцевого результату опанування таймменеджментом (від англ. time management - сукупність методик оптимальної організації часу). Інформаиійна підприємливість може трактуватися як уміння і здатність швидко отримувати необхідну інформацію, оперувати нею для особистої самореалізації або створення нововведень чи здійснення змін. Прагматична підприємливість як елемент підприємницької компетентності фахівця - це особистісна якість, здатність бачити шляхи і способи продуктивного використання інформації, засобів та ситуації загалом для просування у напрямі до досягнення мети (Гуменюк, 2019: 54).

Ми беремо до уваги також те, що відповідно до затвердженого в грудні 2020 року Міністерством освіти і науки України Професійного стандарту за професіями «Вчитель початкових класів закладу загальної середньої освіти» та «Вчитель закладу загальної середньої освіти» виокремлено підприємницьку компетентність як загальну компетентність, що забезпечує здатність до творчого пошуку й реалізації нових ідей, до самопрезентації та результатів своєї професійної діяльності; здатність до керування власним життям і кар'єрою (Наказ Мінекономіки, 2020).

3 урахуванням схарактеризованих наукових позицій нами визначено такі взаємопов'язані структурні компоненти підприємницької компетентності майбутнього вчителя початкової школи: аксіологічно-мотивачійний, інформаиіийно-когнітивний, функиіийно-діяльнісний, особистісно-рефлексивний.

Виокремлення аксіологічно-мотиваційного компонента в структурі підприємницької компетентності майбутнього вчителя початкової школи спричинене тим, що домінуючий вплив на розвиток особистості здійснюють їі потреби, мотиви, сформована система ціннісних настанов до професійної педагогічної діяльності та їі суб'єктів. Цей компонент зумовлює розуміння студентами системи ціннісних властивостей сучасного розвитку підприємливості у професійно-педагогічній діяльності, ціннісних смислів підприємницької діяльності, моральноетичного ставлення до обраної професії.

Інформаційно-когнітивний компонент акумулює сукупність знань підприємницького спрямування, що формують економічну та юридичну грамотність майбутніх учителів початкових класів, та методично зорієнтованих, 
необхідних для ефективної підготовки учнів до здійснення практики підприємництва в рамках освітнього процесу початкової школи. Цей компонент передбачає розуміння студентами ролі підприємництва, його економічних і правових засад у сучасному суспільстві, в умовах економіки знань, ринкових відносин; характеризує спроможність майбутнього вчителя початкової школи оперативно здобувати необхідну інформацію та оперувати нею для особистої самореалізації, створення інновацій чи здійснення змін у площині реалізації компетентнісної парадигми навчання.

Під час виокремлення функційно-діяльнісного компоненту, солідаризуючись із Г. Матуковою (Матукова, 2015) та О. Земкою (Земка, 2018), виходили з того, що він відображає здатність майбутнього вчителя початкової школи планувати, організовувати, проєктувати, контролювати продуктивну підприємницьку професійно-педагогічну діяльність, генерувати нові ідеї й ініціативи та втілювати їх у життя, комунікувати, швидко приймати альтернативні рішення, виявляючи сформованість професійно значущих умінь (аналітичні, проєктувальні, конструктивні, організаторські i комунікативні; навички соціальної взаємодії), комунікабельність, інноваційність, творчість, а також методичних умінь формувати підприємницьку компетентність в учнів початкової школи. Як слушно зауважують учені, цей компонент містить предметну, економічну, мовну, цифрову, науково-дослідницьку компетентність, без яких майбутній учитель буде не спроможний ефективно користуватися «інструментами» підприємницької компетентності в освітньому просторі початкової школи.

Особистісно-рефлексивний компонент представлений особистісно адаптивною компетентністю (репрезентує цілеспрямованість, самостійність, ініціативність, мобільність, відповідальність за прийняті рішення; характеризується здатністю до самоаналізу, оцінювання й інтерпретації результатів власної професійної діяльності, розв'язання проблем, спроможністю прийняття нових рішень для розв'язання проблем, виявлення гнучкості, готовності до змін, самоосвіти і самоорганізації, постійного професійного розвитку), та рефлексивною компетентністю. Щодо рефлексивної складової частини, то вона посідає особливе місце в структурі зазначеного компоненту, позаяк професійна рефлексія дозволяє майбутньому вчителю початкової школи оцінити свої професійні здібності, зіставити їх 3 цілями й очікуваними (планованими) результатами своєї професійної діяльності, краще зрозуміти свої можливості і ресурси, виробити індивідуальний стиль професійної діяльності (Пріма, 2019).

Висновки те перспективи подальших досліджень. Таким чином, резюмуючи викладене, цілком правомірно стверджувати: підприємницька компетентність майбутнього вчителя початкової школи є системною, якісною, інтегративною особистісно-професійною характеристикою, зумовленою його професійною діяльністю, цілісним утворенням, що є сукупністю аксіологічно-мотиваційного, інформаційно-когнітивного, функційнодіяльнісного, особистісно-рефлексивного компонентів, між якими спостерігається взаємозв'язок, взаємодія і взаємозумовленість. Визначення структури підприємницької компетентності майбутнього вчителя початкової школи слугує підгрунтям розроблення адекватної стратегії її розвитку в процесі професійної підготовки, продуктивних механізмів тактичної реалізації, що засвідчує теоретичну i практичну значущість досліджуваної проблеми i, водночас, перспективи подальших досліджень.

\section{ЛІТЕРАТУРА:}

1. Білова Ю. Поняття та структура підприємницької компетентності майбутніх фахівців економічного профілю. Оновлення змісту, форм та методів навчання і виховання в закладах освіти: збірник наукових праць. Наукові записки Рівненського державного гуманітарного університету. 2013. № 7. URL: http://nbuv.gov.ua/UJRN/ Ozfm_2013_7_7

2. Бондар Н.Д. Формування ключових компетентностей майбутніх менеджерів сфери туризму в процесі вивчення гуманітарних дисциплін : дис. ... канд. пед. наук: 13.00.04. Вінниця, 2016.

3. Гуменюк I. Формування підприємницької компетентності майбутніх фахівців педагогічного профілю. Педагогічна освіта: теорія і практика : зб. наук. праць ; Кам'янець-Подільський національний університет імені Івана Огієнка ; Інститут педагогіки НАПН України. Кам’янець-Подільський, 2019. Вип. 26(1). Ч. 1. 
4. Земка О.В. Модель формування підприємницької компетентності у майбутніх учителів технологій. Науковий часопис НПУ імені М.П. Драгоманова. Київ. 2017. Серія 16. Вип. 29(39). С. 110-114.

5. Земка О.В. Формування підприємницької компетентності в майбутніх учителів технологій у процесі професійної підготовки : дис. ... канд. пед. наук : 13.00.04. Глухів, 2018.

6. Кошевська К. Підприємливість та ініціативність серед інших ключових компетентностей. Уроки з підприємницьким тлом : навч. матер. / за заг. ред. Е. Бобінської, Р. Шияна, М. Товкало. Варшава, 2014.

7. Листопад О.А. Теоретико-методичні засади формування професійно-творчого потенціалу майбутніх вихователів дошкільних навчальних закладів : дис.. д-ра пед. наук : 13.00.04; 13.00 .08 ; Південноукраїнський національний педагогічний університет імені К.Д. Ушинського, Одеса.

8. Ляшенко М.Ю. Формування фахової компетентності з основпідприємництва у майбутніх учителів технологій : дис. ... канд. пед. наук : 13.00.02. Київ, 2017.

9. Майковська В.І. Сутність і структура підприємницької компетентності майбутніх фахівців в Україні. Вісник Житомирського державного університету імені Івана Франка. Серія: Педагогічні науки. 2017. № 1(87). С. 112-117.

10. Матукова Г.І. Підприємницька компетентність майбутніх фахівців економічного профілю: теорія і практика : монографія. Кривий Ріг : Видавець ФОП Чернявський Д.О., 2015.

11. Морзе Н., Балик Н. Шляхи формування підприємницької компетентності майбутніх інформатиків. Інформатика та інформаційні технології в навчальних закладах : науково- методичний журнал. 2015. № 1. С. 8-17.

12. Наказ Міністерства розвитку економіки, торгівлі та сільського господарства України «Про затвердження професійного стандарту за професіями «Вчитель початкових класів закладу загальної середньої освіти», «Вчитель закладу загальної середньої освіти», «Вчитель 3 початкової освіти (з дипломом молодшого спеціаліста)». 2020. URL: https://zakon.rada.gov.ua/rada/show/v2736915-20\#Text

13. Пискун О.М., \& Сокол Н.В. Розвиток підприємливості та фінансової грамотності учнів старшої школи в процесі технологічної освіти. Вісник Чернігівського наи. пед. унів.-му. Серія: Педагогічні науки. 2018. Вип. 151(2). С. 118-122.

14. Пріма Д.А. Професійна позиція майбутнього вчителя початкової школи: структурно-компонентна характеристика. Вісник Наџіональної академії Державної прикордонної служби України. Серія: Педагогіка, 2. 2019. URL: http://nbuv.gov.ua/UJRN/Vnadped_2019_2_17

15. Проценко О. Підприємницькі уміння як складник життєвої компетентності учнів професійно-технічних навчальних закладів. Педагогіка формування творчої особистості у вищій $i$ загальноосвітній школах. 2013. Вип. 30(83). С. 298-301.

16. Ткаченко М.В. Формування підприємницької компетентності майбутніх фахівців ресторанного господарства у професійно-технічних навчальних закладах : дис канд. пед. наук : 13.00.04. Київ, 2018.

\section{REFERENCES:}

1. Bilova, Yu. (2013). Poniattia ta struktura pidpryiemnytskoi kompetentnosti maibutnikh fakhivtsiv ekonomichnoho profiliu [The concept and structure of entrepreneurial competence of future economic professionals]. Onovlennia zmistu, form ta metodiv navchannia i vykhovannia v zakladakh osvity: zbirnyk naukovykh prats. Naukovi zapysky Rivnenskoho derzhavnoho humanitarnoho universytetu. 7. Rezhym dostupu: http://nbuv.gov.ua/UJRN/Ozfm_2013_7_7 [in Ukrainian].

2. Bondar, N.D. (2016). Formuvannia kliuchovykh kompetentnostei maibutnikh menedzheriv sfery turyzmu v protsesi vyvchennia humanitarnykh dystsyplin [Formation of key competencies of future managers in the field of tourism in the study of humanities] ( $\mathrm{PhD}$ thesis: 13.00.04). Vinnytsia [in Ukrainian].

3. Humeniuk, I. (2019). Formuvannia pidpryiemnytskoi kompetentnosti maibutnikh fakhivtsiv pedahohichnoho profiliu. Pedahohichna osvita: teoriia i praktyka [Formation of entrepreneurial competence of future pedagogical specialists]: Zb. nauk. prats. Kamianets-Podilskyi natsionalnyi universytet imeni Ivana Ohiienka; Instytut pedahohiky NAPN Ukrainy [hol. red. Labunets V.M.]. Vyp. 26 (1). Ch.1. Kamianets-Podilskyi [in Ukrainian].

4. Zemka, O.V. (2017). Model formuvannia pidpryiemnytskoi kompetentnosti u maibutnikh uchyteliv tekhnolohii [Model of formation of entrepreneurial competence in future technology teachers]. Naukovyi chasopys NPU imeni M. P. Drahomanova. Kyiv. Seriia 16. Vyp. 29 (39). 110-114 [in Ukrainian].

5. Zemka, O.V. (2018). Formuvannia pidpryiemnytskoi kompetentnosti $\mathrm{v}$ maibutnikh uchyteliv tekhnolohii u protsesi profesiinoi pidhotovky [Formation of entrepreneurial competence in future technology teachers in the process of professional training] ( $\mathrm{PhD}$ thesis: 13.00.04). Hlukhiv [in Ukrainian].

6. Koshevska, K. (2014). Pidpryiemlyvist ta initsiatyvnist sered inshykh kliuchovykh kompetentnostei [Entrepreneurship and initiative are among the other key competencies]. Uroky z pidpryiemnytskym tlom : navch. mater. / za zah. red. E. Bobinskoi, R. Shyiana, M. Tovkalo. Varshava.

7. Lystopad, O.A. (2016). Teoretyko-metodychni zasady formuvannia profesiino-tvorchoho potentsialu maibutnikh vykhovateliv doshkilnykh navchalnykh zakladiv [Theoretical and methodical baces of formftion of professional and 
creative potential of future educators of preschool educational institutions] (dys. ... dok. ped.. nauk, 13.00.04, 13.00.08). Odesa [in Ukrainian].

8. Liashenko, M. Yu. (2017). Formuvannia fakhovoi kompetentnosti z osnov pidpryiemnytstva u maibutnikh uchyteliv tekhnolohii [Formation of professional competence in the basics of entrepreneurship in future teachers of technology] (PhD thesis: 13.00.02). Kyiv [in Ukrainian].

9. Maikovska, V. I. (2017). Sutnist i struktura pidpryiemnytskoi kompetentnosti maibutnikh fakhivtsiv v Ukraini [The essence and structure of entrepreneurial competence of future professionals in Ukraine]. Visnyk Zhytomyrskoho derzhavnoho universytetu imeni Ivana Franka. Seriia : Pedahohichni nauky, 1 (87), 112-117 [in Ukrainian].

10. Matukova, H. I. (2015). Pidpryiemnytska kompetentnist maibutnikh fakhivtsiv ekonomichnoho profiliu: teoriia i praktyka [Entrepreneurial competence of future economic specialists: theory and practice]: monohrafiia. Kryvyi Rih: Vydavets FOP Cherniavskyi D. O. [in Ukrainian].

11. Morze, N., Balyk, N. (2015). Shliakhy formuvannia pidpryiemnytskoi kompetentnosti maibutnikh informatykiv [Ways of formation of entrepreneurial competence of future computer scientists]. Informatyka ta informatsiini tekhnolohii v navchalnykh zakladakh: naukovo- metodychnyi zhurnal. № 1. S. 8-17 [in Ukrainian].

12. Nakaz Ministerstva rozvytku ekonomiky, torhivli ta silskoho hospodarstva Ukrainy «Pro zatverdzhennia profesiinoho standartu za profesiiamy «Vchytel pochatkovykh klasiv zakladu zahalnoi serednoi osvity», «Vchytel zakladu zahalnoi serednoi osvity», «Vchytel z pochatkovoi osvity (z dyplomom molodshoho spetsialista)» (Order of the Ministry of Economic Development, Trade and Agriculture of Ukraine. «On approval of the professional standard for the professions «Primary school teacher of general secondary education», «Teacher of general secondary education», «Primary education teacher (with a diploma of junior specialist)»). 2020. Retrieved from: https://zakon.rada.gov.ua/rada/ show/v2736915-20\#Text [in Ukrainian].

13. Pyskun, O. M., \& Sokol, N. V. (2018). Rozvytok pidpryiemlyvosti ta finansovoi hramotnosti uchniv starshoi shkoly $\mathrm{v}$ protsesi tekhnolohichnoi osvity [Development of entrepreneurship and financial literacy of high school students in the process of technological education]. Visnyk Chernihivskoho nats. ped. univ.-tu. Seriia: Pedahohichni nauky. Vyp. 151(2). 118-122 [in Ukrainian].

14. Prima, D. A. (2019). Profesiina pozytsiia maibutnoho vchytelia pochatkovoi shkoly: strukturno-komponentna kharakterystyka [Professional position of the future primary school teacher: structural-component characteristics]. Visnyk Natsionalnoi akademii Derzhavnoi prykordonnoi sluzhby Ukrainy. Seriia: Pedahohika, 2. Vziato z http://nbuv.gov.ua/UJRN/Vnadped_2019_2_17 [in Ukrainian].

15. Protsenko, O. (2013). Pidpryiemnytski uminnia yak skladnyk zhyttievoi kompetentnosti uchniv profesiinotekhnichnykh navchalnykh zakladiv [Entrepreneurial skills as a component of life competence of students of vocational schools]. Pedahohika formuvannia tvorchoi osobystosti u vyshchii i zahalnoosvitnii shkolakh. Vyp. 30 (83). S. 298-301 [in Ukrainian].

16. Tkachenko, M. V. (2018). Formuvannia pidpryiemnytskoi kompetentnosti maibutnikh fakhivtsiv restorannoho hospodarstva u profesiino-tekhnichnykh navchalnykh zakladakh [Formation of entrepreneurial competence of future restaurant specialists in vocational schools] ( $\mathrm{PhD}$ thesis: 13.00.04). Kyiv [in Ukrainian]. 